\title{
GOSPODARSKA KRIZA I POŽELJNOST ODABIRA VOJNOG POZIVA
}

Dario MATIKA, Marinko OGOREC

Instituł za istraživanje i razvoj obrambenih sustava MORH-a, Zagreb

UDK: 338.124.4(497.5):355.087.2

Prethodno priopćenje

Primlieno: 19. 12. 2010.

U okolnostima povećane osobne nesigurnosti, zbog ekonomsko-financijske krize koja je snažno pogodila i Republiku Hrvatsku, u određenoj mjeri promijenila se i poželinost odabira vojne profesije. Otkako je nastupila gospodarska kriza u Republici Hrvatskoj i s njom osobna ekonomska nesigurnost, pristup mlađih naraštaja vojnoj profesiji počeo se mijenjati, pa i stavovi o vlastitu uključivanju u oružane snage i vojnoj profesiji kao životnom (ili barem dugoročnom) odabiru. Istraživanje je pokazalo kako je 2010. godine u nešto većoj mieri porasla prihvatliivost dragovoline ročne službe kod anketiranih obveznika u usporedbi s prethodnim godinama, međutim stavovi prema djelatnoj vojnoj službi nisu se zamjetnije promijenili. Takvi rezultati mogu se tumačiti kao razmišljanje o mogućem privremenom rješenju ekonomske nesigurnosti u razdoblju recesijske krize, a dugoročno velika većina anketiranih doživljava vojnu profesiju tek kao "izlaz u nuždi", ako se neće moći zaposliti u građanstvu.

Ključne riječi: gospodarska kriza, vojna profesija, dragovoljna vojna služba

$\triangle \quad$ Dario Matika, Institut za istraživanje i razvoj obrambenih sustava MORH-a, llica 256b, objekt 36, 10000 Zagreb, Hrvatska.

E-mail: dario.matika@morh.hr

\section{UVOD}

Velika ekonomsko-financijska kriza, koja je sredinom 2008. godine poprimila globalne razmjere, vrlo je snažno pogodila veći broj zemalja u tranziciji, među kojima i Republiku Hrvatsku, uzrokujući ozbiljnu gospodarsku destabilizaciju i porast neza- 
DRUŠ. ISTRAŽ. ZAGREB GOD. 21 (2012),

BR. 1 (115),

STR. $121-136$

MATIKA, D., OGOREC, M. GOSPODARSKA KRIZA... poslenosti. U okolnostima povećane osobne ekonomske nesigurnosti, u određenoj mjeri promijenila se i poželjnost odabira vojne profesije, koja postaje zanimljiva većem broju građana nego što je to bilo prije izbijanja gospodarske krize. U radu se razmatra odnos između gospodarske krize u Republici Hrvatskoj i njezina utjecaja na ekonomsku sigurnost građana i poželjnosti vojne profesije kao jednog od pouzdanih načina dugoročnog ostvarenja ekonomske sigurnosti. Osim toga, razmatra se i podudarnost između poželjnosti vojne profesije u okolnostima izražene gospodarske krize i stavova građana Republike Hrvatske prema vlastitim oružanim snagama.

\section{Gospodarska kriza i ekonomska (ne)sigurnost u Republici Hrvatskoj}

Financijsko-ekonomske krize, među koje se svakako može uvrstiti i aktualna gospodarska kriza u Republici Hrvatskoj, posebna su skupina kriznih situacija koje u velikoj mjeri utječu na osobnu sigurnost pučanstva, jer sigurnost pojedinca danas je u velikoj mjeri određena gospodarskim stanjem i mogućnošću ostvarenja egzistencije $\mathrm{u}$ funkcionalnim gospodarskim okvirima. Nov konceptualni pristup ekonomskoj sigurnosti teži minimaliziranju prijetnje koju može izazvati udar financijsko-ekonomske krize (osobito na egzistencijalni status pojedinca) te maksimiziranju osobnih mogućnosti, pri čemu "težnja za postizavanjem tih mogućnosti uključuje očuvanje strukturnog identiteta i sposobnosti za stvaranje prosperiteta i interesa političko-ekonomskog entiteta u kontekstu različitih izvanjskih rizika i prijetnji s kojima se suočava u međunarodnom ekonomskom sustavu" (Dent, 2010., 241).

Globalizacija svjetskoga tržišta roba, usluga i novca, koja je danas vrlo aktualna, nije isključivo obilježje gospodarskih tijekova samo na kraju XX. i na početku XXI. stoljeća nego se u razdobljima povijesti javljala i ranije, pri čemu su ih (u većoj ili manjoj mjeri) redovito pratile i ekonomske krize, nastale u jednako tako različitim okolnostima i s različitim posljedicama. ${ }^{1}$ U skladu s tim, globalizacijske promjene osobito su pogodile zemlje s tranzicijskim gospodarstvom, nastalim slomom socijalističkoga političko-gospodarskog sustava, što je rezultiralo novim financijsko-gospodarskim krizama, pri čemu je pritisak međunarodne konkurencije doveo do socijalnih posljedica, koje su u pojedinim slučajevima rezultirale političkom i vojnom destabilizacijom najviše pogođenih zemalja. ${ }^{2} \mathrm{Na}$ taj način i sam proces globalizacije podvrgnut je kritičkim prosudbama, po kojima je "globalizacija stvorila novu definiciju ekonomske sigurnosti, usredotočene na dva neočekivana procesa prerastanja nacionalnih granica - teško kontrolirane toko- 
DRUŠ. ISTRAŽ. ZAGREB GOD. 21 (2012), BR. 1 (115),

STR. $121-136$

MATIKA, D., OGOREC, M. GOSPODARSKA KRIZA...

(1) DIJAGRAM 1 Kretanje godišnje stope BDP-a Republike Hrvatske a koje je relativno jednostavno maskirati u legitimna sredstva i ekonomske šokove koji mogu narušiti gospodarski rast, te izazvati gospodarsku nejednakost i političku nestabilnost" (Kahler, 2004.). ${ }^{3}$ Svojevrsnu potvrdu takvih percepcija dala je i najnovija kriza nastala sredinom 2007. godine na američkom financijskom tržištu, koja se prelila u globalnu kreditnu krizu potkraj te i na početku 2008. godine. Sredinom te godine prerasla je $u$ globalnu gospodarsku krizu, koja je većinu razvijenih zemalja bacila u recesiju, pri čemu je stvoreno duboko, globalno nepovjerenje $u$ sustav financijskih tržišta i njegove know-how regulatore, koji (prema mnogim nezavisnim analitičarima) nisu učinili dovoljno na sprečavanju rizika za financijska tržišta razvijenih zemalja (Petrov, 2008.).

Kako Hrvatska nije izdvojena iz globalnih financijskih tokova, usporavanje globalnoga gospodarstva moralo se odraziti i na usporavanje domaće ekonomije, pa je vrlo brzo hrvatsko gospodarstvo pogodila najsnažnija financijsko-gospodarska kriza od njezina osamostaljenja i stjecanja državnoga suvereniteta. S druge strane, nužno je naglasiti kako ta međunarodna financijsko-gospodarska kriza nije isključiv razlog usporavanja hrvatskoga gospodarstva i jedini krivac aktualne gospodarske depresije u Hrvatskoj, u kojoj je kriza endogeno generirana tijekom razmjerno dugog razdoblja, prije izbijanja već navedene krize međunarodnih razmjera. ${ }^{4}$

Ekonomska sigurnost suvremenoga hrvatskog društva podjednako je ugrožena $u$ društvenom i $u$ individualnom segmentu njezinih građana kroz smanjivanje BDP-a (dijagram br. 1), slabljenjem kupovne moći (dijagram br. 2) i naglim porastom nezaposlenosti (dijagram br. 3 ).

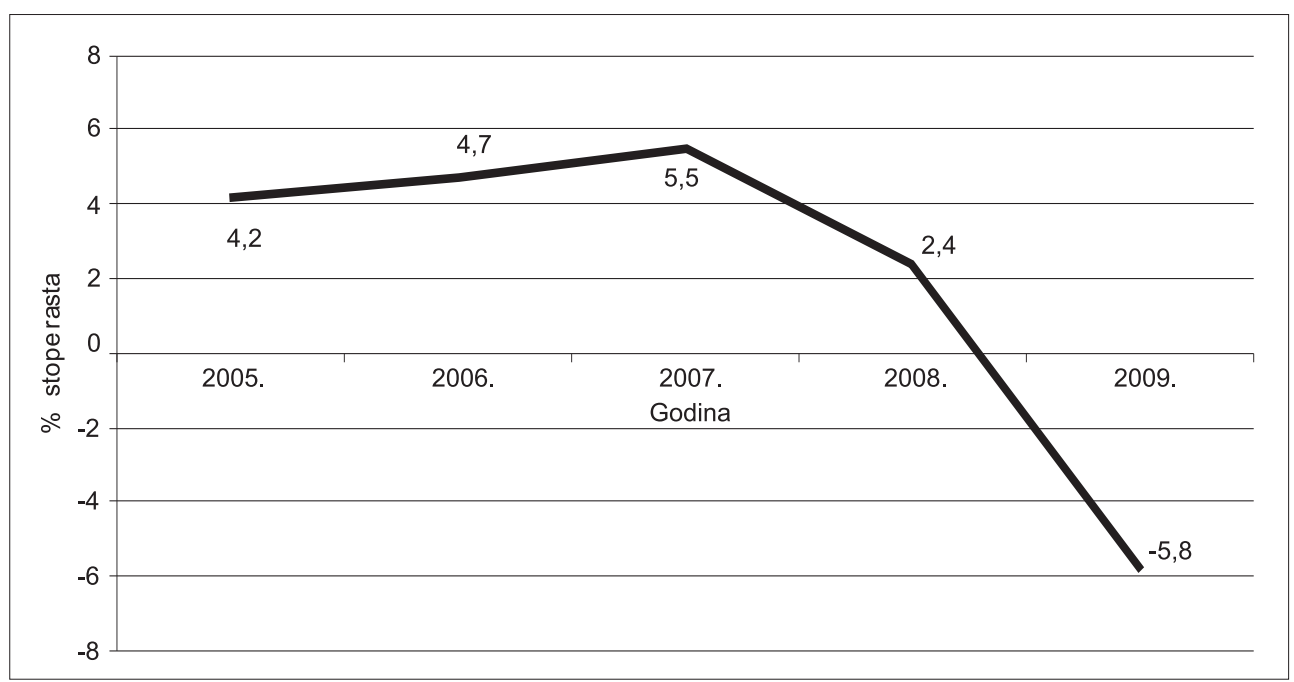

Izvor: Državni zavod za statistiku RH (2010.) 


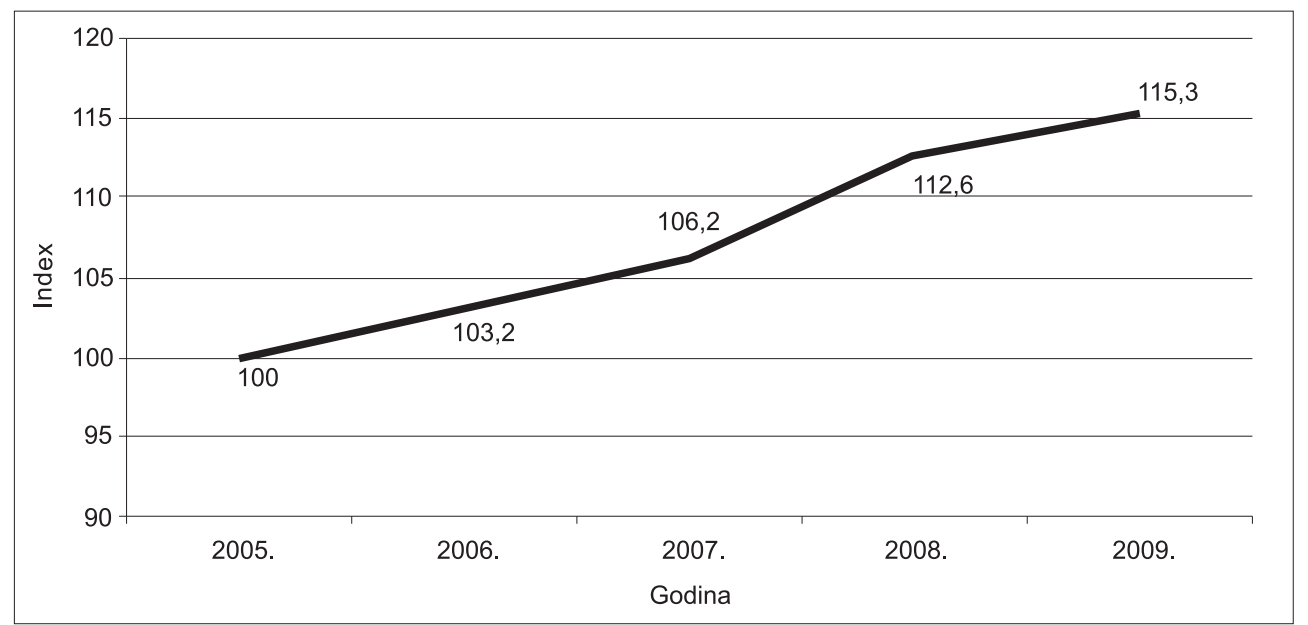

Izvor: Državni zavod za statistiku RH (2010.)

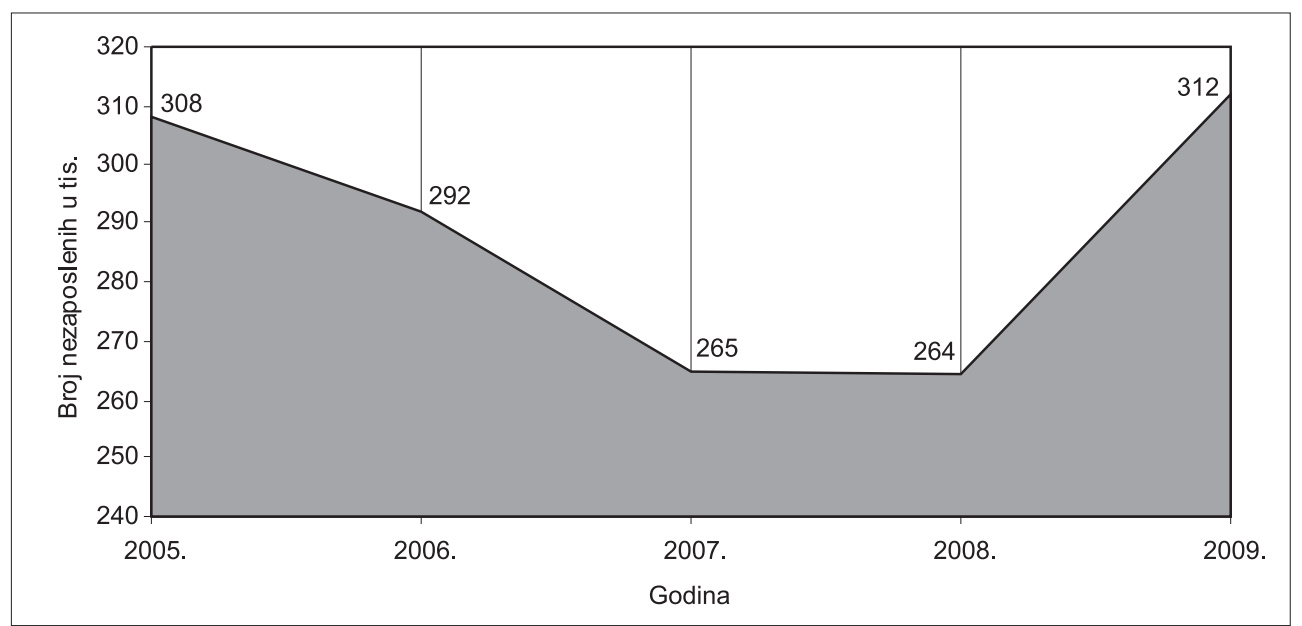

Izvor: Državni zavod za statistiku RH (2010.)

Dก DIJAGRAM 2

Kretanje indeksa rasta potrošačkih ciijena

\section{- DIJAGRAM 3}

Kretanje prosječnoga broja nezaposlenih po godinama
Ti nepovoljni čimbenici izravno se odražavaju na stvaranje klime anksioznosti i nesigurnosti u cijelom društvu, pri čemu sve veću društvenu vrijednost dobiva sigurnost radnog mjesta, bolje rečeno zadržavanje mogućnosti rada u dužem razdoblju, uz sigurnost primanja odgovarajuće zarade za uloženi rad. Imajući na umu da je upravo nezaposlenost najradikalnija prijetnja ekonomskoj sigurnosti pojedinca, mogućnost zapošljavanja u državnom sektoru, koji još uvijek čini drugo po redu područje zapošljavanja (dijagram br. 4), sve više dobiva na važnosti, jer osigurava znatno veću radnu sigurnost i prava zaposlenika (redovite prihode, regulirano radno i slobodno vrijeme, zakonsku zaštitu uvjeta rada i sl.) od ostalih sektora, koji su sve više izloženi nesmiljenosti tržišnoga natjecanja, pa samim tim i visokoj konkurenciji radne snage. 


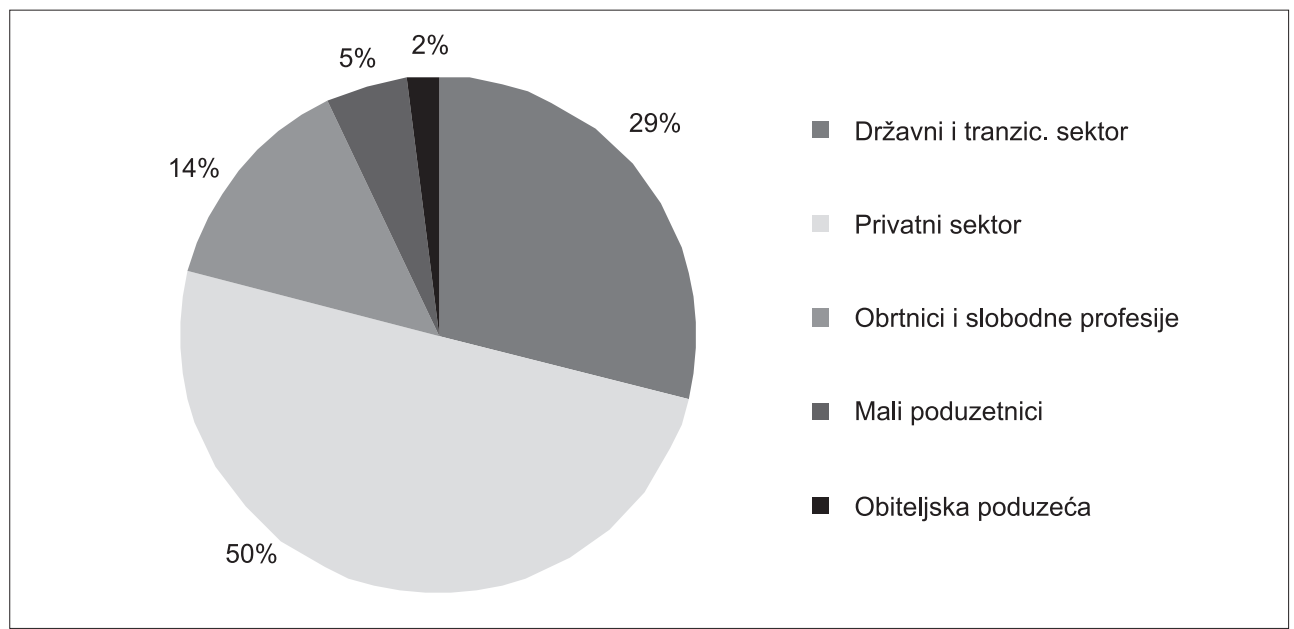

Izvor: Hrvatska u brojkama 2010., 10

(1) DIJAGRAM 4

Područja zapošljavanja po sektorima
U svakom slučaju, gospodarska kriza i sve veća ekonomska nesigurnost, reflektirajući se na socijalni status i strukturu pučanstva, u većoj ili manjoj mjeri utječu na promjenu društvenih vrijednosti i općih stavova prema pojedinim društvenim čimbenicima, institucijama i procesima. Zbog toga se može pretpostaviti da je, posebno u kontekstu sve izraženijeg rasta nezaposlenosti, došlo i do promjena u percepciji poželjnosti i prihvatljivosti vojnoga poziva.

\section{Odnos hrvatskoga društva prema vlastitim oružanim snagama}

Oružane snage Republike Hrvatske stvorene su u najdramatičnijem razdoblju novije hrvatske povijesti - kao Hrvatska vojska izrasle su iz same strukture društva tijekom Domovinskog rata, koji su pobjedonosno završile, u najvećoj mjeri omogućivši stvaranje državne samostalnosti i suvereniteta. Ta činjenica stvorila im je moralni kapital u hrvatskom društvu, koje u relativno visokom stupnju ima pozitivan stav prema svojim oružanim snagama (dijagram br. 5). Iz dijagrama se vidi kako većina anketiranih ima pozitivan stav prema Oružanim snagama Republike Hrvatske, a isto tako gotovo trećina ispitanika iskazala je svojevrsnu ravnodušnost ili nije imala stav o tom pitanju, dok se samo 1,9\% anketiranih izjasnilo za izrazito negativan stav prema OS RH.

Prilikom komparativnog istraživanja povjerenja građana $\mathrm{u}$ razne društvene institucije, tijekom znanstveno-istraživačkog projekta "Hrvatska vojska - hrvatsko društvo", oružane snage visoko su vrednovane i praktički su zauzele II. mjesto (odmah nakon obrazovnoga sustava), ${ }^{5}$ u većoj ili manjoj mjeri nadmašivši ostale državne strukture i druge društvene insti- 
DIJAGRAM 5

Osobni stav ispitanika prema OS RH

(1) DIJAGRAM 6

Povjerenje javnosti u

društvene instituciie

Republike Hrvatske
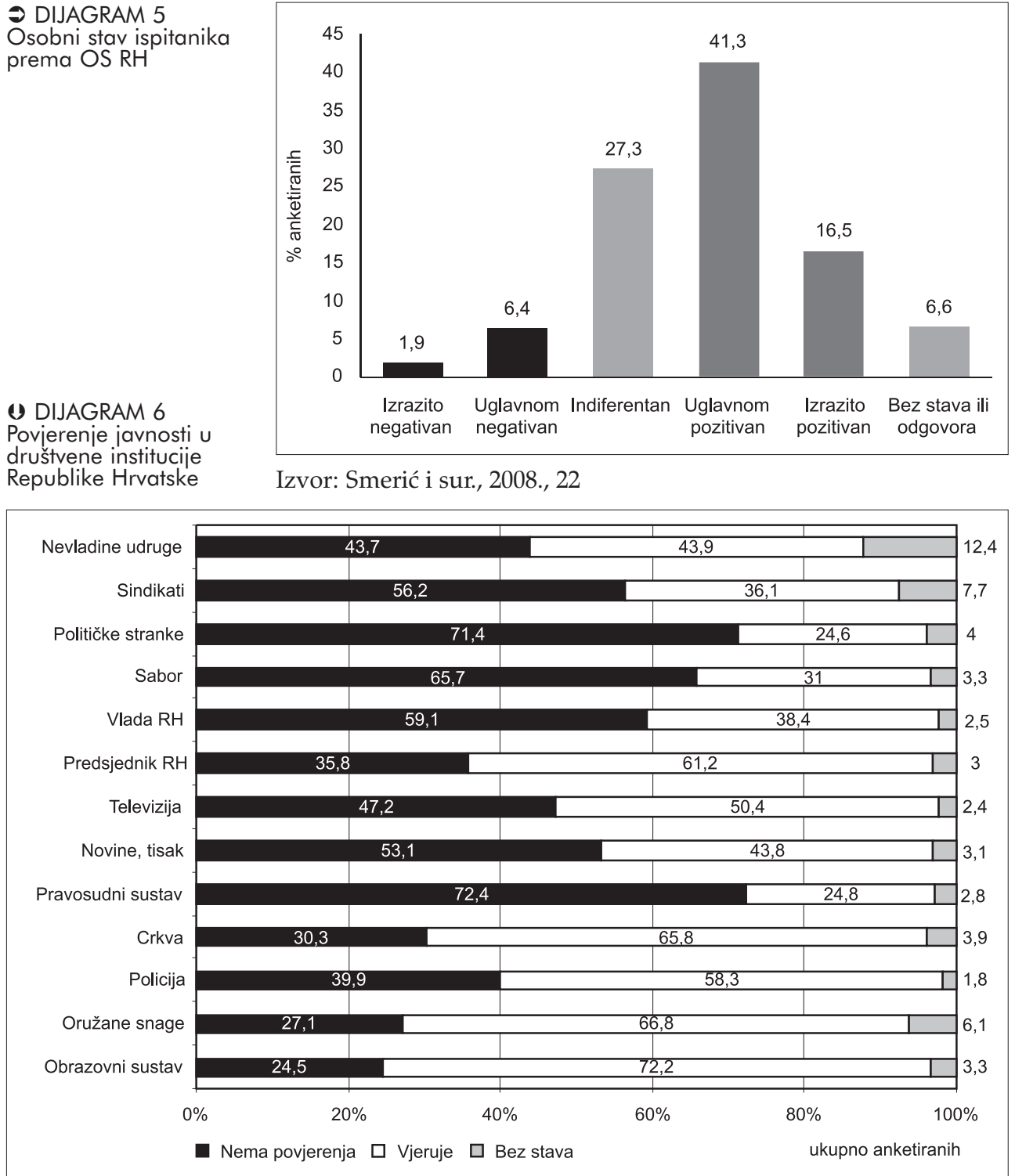

Izvor: Smerić i sur., 2008., 23

Povjerenje oružanim snagama $u$ većoj su mjeri iskazali stariji ispitanici (iznad 50 godina života) u odnosu na ispitanike mlađe od 30 godina, a ispitanici s pozitivnim osobnim stavom prema OS RH bili su skloniji poklanjanju višega stupnja povjerenja u odnosu na ispitanike s prevladavajuće negativnim osobnim stavom (što se moglo i očekivati).

Treba naglasiti kako u usporedbi s rezultatima sličnih istraživanja provedenih $u$ drugim europskim zemljama postoji velika podudarnost stajališta hrvatske javnosti i javnosti po- 
DRUŠ. ISTRAŽ. ZAGREB GOD. 21 (2012), BR. 1 (115),

STR. $121-136$

MATIKA, D., OGOREC, M. GOSPODARSKA KRIZA... jedinih europskih zemalja, pri čemu je povjerenje javnosti u vlastite nacionalne oružane snage najviše bilo izraženo u Finskoj (89\%), Grčkoj (88\%) i Velikoj Britaniji (82\%), dok je najmanje bilo u Belgiji (62\%), Španjolskoj (63\%) i Luksemburgu (65\%). Primjer SAD-a isto tako pokazuje da je iskazivanje visokoga stupnja povjerenja $u$ oružane snage gotovo univerzalno obilježje raspoloženja javnosti suvremenih društava Zapada (Smerić i sur., 2008., 24).

U konačnici, navedeno istraživanje pokazalo je kako većina anketiranih građana ocjenjuje pojedina obilježja Oružanih snaga Republike Hrvatske vrlo dobrom ocjenom (s iznimkom tehničke opremljenosti, koja je najniže rangirana), pri čemu su najviše rangirani odanost vrijednostima Domovinskog rata i profesionalnost. ${ }^{6}$ Valja naglasiti kako je manje od jedne desetine ispitanika Oružane snage Republike Hrvatske ocijenilo lošim ocjenama (nedovoljan i dovoljan), i to u rasponu 5,6\% svih ispitanika za profesionalnost i $8,1 \%$ za odanost vrijednostima Domovinskog rata (Franc i sur., 2008., 43). U prilog ovakvim ocjenama ide i prilično izražena emocionalna naklonost građana Republike Hrvatske svojim oružanim snagama, pa se npr. relativna većina ispitanika $(45,5 \%)$ izjasnila kako često ili vrlo često ima osjećaj ponosa na svoje oružane snage, a više od $1 / 3$ često ili vrlo često doživljava osjećaj zadovoljstva. U isti mah negativni osjećaji prema Oružanim snagama prilično su rijetko zastupljeni, što dodatno potvrđuje ukupno pozitivan stav ispitanika prema njima. Osobito negativne emocije, kao što su sram ili nelagoda, velika većina ispitanika vrlo rijetko ili nikad ne doživljava u vezi s Oružanim snagama, pri čemu su ispitanici uglavnom bili kategorični u odgovorima (npr. 67,2\% ispitanika izjavilo je kako nikada nemaju osjećaj srama, vezano uz hrvatske oružane snage, a osjećaj nelagode nikada ne doživljava $63,2 \%$ ). U svakom slučaju, očito je kako (sudeći po stavovima ispitnog uzorka) u hrvatskom društvu postoji prilično visok stupanj prihvaćanja vlastitih oružanih snaga, s čijim se pripadnicima ostali građani mogu relativno lako poistovjetiti i solidarizirati.

\section{Odnos hrvatskoga društva prema vojnoi profesiji}

Toliko pozitivan stav društva prema oružanim snagama u velikoj mjeri odražava se i na percepciju vojne profesije, koju društvo u načelu smatra odgovornom, časnom, uglednom i uglavnom poželjnom. Istraživanja provedena prije radikalnog izbijanja manifestacija financijsko-ekonomske krize pokazuju vrlo solidno pozicioniranje ugleda vojne profesije $\mathrm{u}$ hrvatskom društvu (dijagram br. 7). ${ }^{7}$

Analiza procjena društvenog ugleda vojne profesije $\mathrm{u}$ hrvatskom društvu pokazala je da ga relativna većina ispitani- 
DRUŠ. ISTRAŽ. ZAGREB GOD. 21 (2012),

BR. 1 (115),

STR. $121-136$

MATIKA, D., OGOREC, M. GOSPODARSKA KRIZA...

\section{DIJAGRAM 7} Mišljenje o razini ugleda voine časničke profesiie ka percipira umjereno natprosječnim (za ocjene 3 i 4 odlučilo se ukupno $47,4 \%$ anketiranih). No unatoč općenitoj naklonosti prema vlastitim oružanim snagama i načelno pozitivnim stavovima prema vojnoj profesiji, u nekoliko zadnjih godina relativno manji broj mladih ljudi (u odnosu na potrebe oružanih snaga, naravno) odlučivao se za nastavak svoje karijere u vojnom pozivu. Kratko rečeno, deklarativno su imali pozitivan stav o hrvatskim oružanim snagama i vojnoj profesiji kao takvoj, ali osobno nisu bili zainteresirani za svoj vojnički profesionalni razvoj. Takav je pristup na svojevrstan način imao i širu potporu javnosti, što se pokazalo i projektom "Hrvatska vojska - hrvatsko društvo", jer je relativna većina ispitanika bila prilično nesklona odabiru vojne profesije (dijagram br. 8), pa čak i dragovoljnom služenju vojnog roka za članove vlastite obitelji ili bliskih prijatelja (dijagram br. 9).

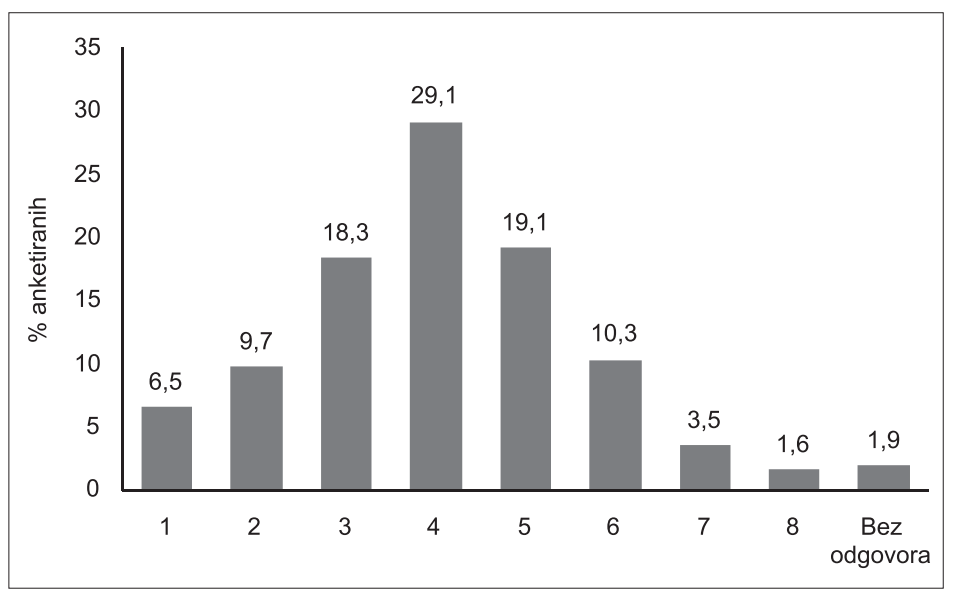

Izvor: Smerić i sur., 2008., 38

Biste li bliskoj osobi (članu obitelji ili prijatelju) savjetovali da izabere karijeru časnika, dočasnika ili vojnika u OS $\mathrm{RH}$ ?

$\%$ anktetiranih odabira vojine profesije kao životnoga poziva

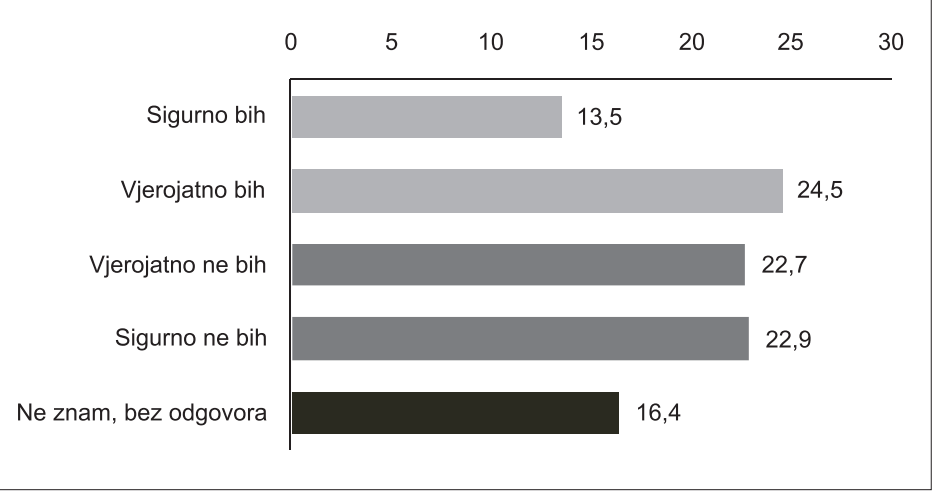

Izvor: Smerić i sur., 2008., 42 
$\rightarrow$ DIJAGRAM 9

Stajališta o preporuci dragovolinoga služenja voinog roka

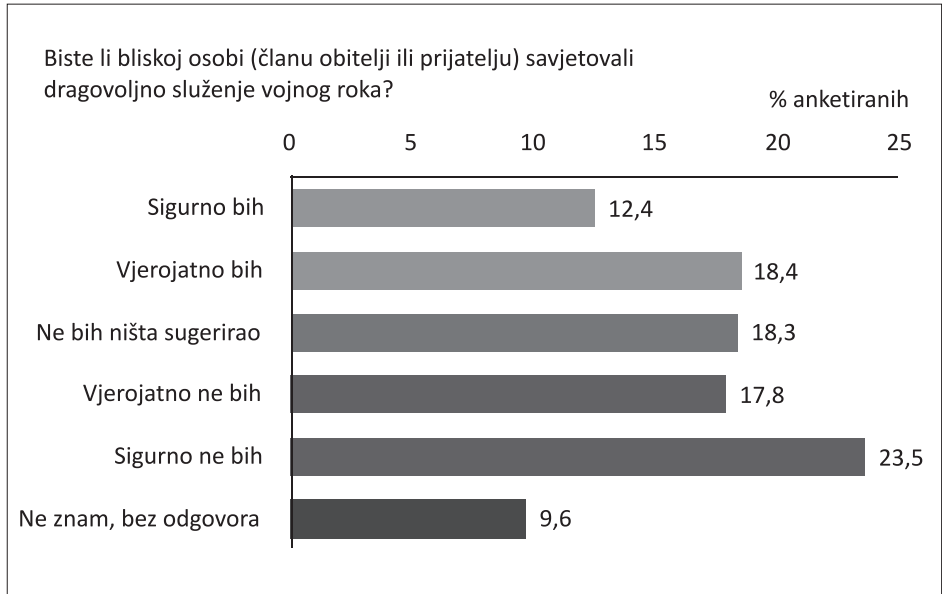

Izvor: Smerić i sur., 2008., 47

Uzroci takvoj dihotomiji kompleksni su i višestruko isprepleteni, pa svakako traže zasebnu temu istraživanja, međutim pojednostavnjeno se može zaključiti kako se u ratu stvorene hrvatske Oružane snage (s u ratu definiranim časničkim zborom) $\mathrm{u}$ poratnom razdoblju suočavaju s nizom novih izazova, koji u velikoj mjeri determiniraju društveni ugled vojne profesije, ali i očekivanja profesionalnih pripadnika oružanih snaga (detaljnije u Smerić, 2001., 15-17).

Otkako je nastupila gospodarska kriza u Republici Hrvatskoj i s njome osobna ekonomska, pa u nerijetkim slučajevima i egzistencijalna, nesigurnost, pristup mlađih naraštaja vojnoj profesiji počeo se mijenjati, pa i stavovi o vlastitu uključivanju u oružane snage i vojnoj profesiji kao životnom (ili barem dugoročnom) odabiru. Pritom u velikoj mjeri temeljni motivacijski čimbenik postaje mogućnost otklanjanja ili ublažavanja osobne ekonomske nesigurnosti - tzv. "moderni tip" motivacije, koji naglašava instrumentalnu ili utilitarnu predanost (Battistelli, 1997., prema Smerić, 2005., 340-341). ${ }^{8}$

Promjenu stavova prema vojnoj profesiji evidentiralo je i redovito istraživanje koje već četvrtu godinu zaredom provodi Odsjek za vojnu psihologiju Personalne službe Ministarstva obrane Republike Hrvatske u suradnji sa Službom za vojnu obvezu na obveznicima upisa u vojnu evidenciju.

\section{Istraživački nalazi}

Unutar sustava Ministarstva obrane kontinuirano se od 2007. godine provodi istraživanje na petpostotnim reprezentativnim uzorcima ${ }^{9}$ upisnika u vojnu evidenciju, s ciljem prikupljanja podataka o zainteresiranosti potencijalnih kandidata za vojni poziv i utvrđivanja broja potencijalnih zaposlenika u Oružanim snagama Republike Hrvatske u svojstvu djelatne vojne 
DRUŠ. ISTRAŽ. ZAGREB GOD. 21 (2012)

BR. 1 (115),

STR. $121-136$

MATIKA, D., OGOREC, M. GOSPODARSKA KRIZA...

DIJAGRAM 10 ranosti za dragovolino služenje vojnog roka osobe. Anketiranje obveznika upisa u vojnu evidenciju za 2009. godinu provedeno je u veljači kao anonimno i pojedinačno psihologijsko ispitivanje na slučajnom odabranom uzorku uz njihovu suglasnost, a proveli su ga djelatnici Ureda za obranu, koji i provode upis u vojnu evidenciju.

Rezultati istraživanja u usporedbi s prethodnim godinama pokazali su znatno veću prihvatljivost dragovoljnoga služenja vojnog roka (dijagram br. 10). Naime, i u ispitivanju tijekom 2009. godine uvjerljivo najveći broj ispitanika bio je neodlučan o ulasku u dragovoljnu ročnu službu, čak i veći nego $\mathrm{u}$ prethodnim godinama, ali je istodobno povećan broj ispitanika kojima je potpuno prihvatljivo dragovoljno služenje u ročnom sastavu, dok se $u$ isti mah $u$ velikoj mjeri smanjio broj anketiranih koji su odlučno odbacivali takvu mogućnost.

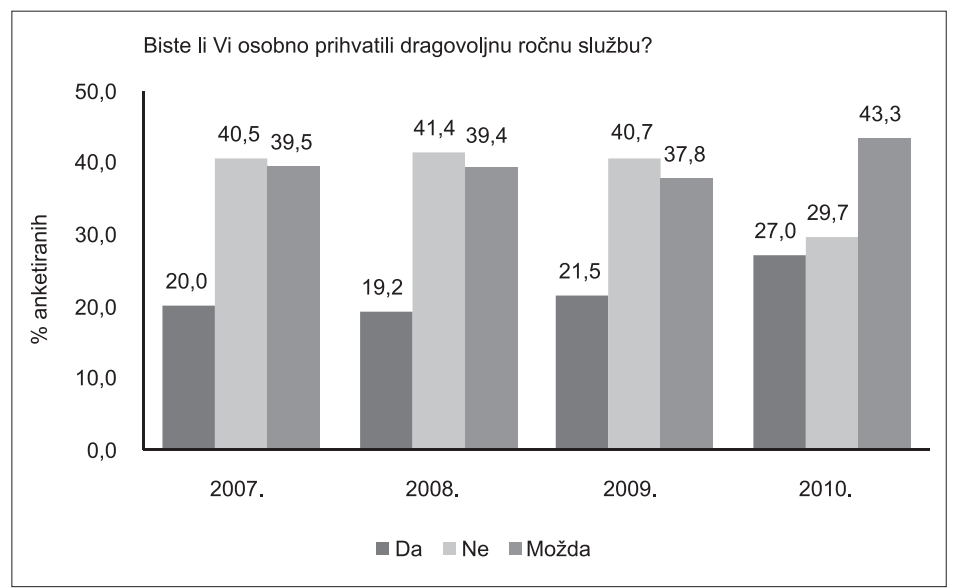

Izvor: Izvješće o stavovima novaka o vojnoj službi tijekom upisa u vojnu evidenciju, 2010., 10

Usporedba rezultata iz 2009. godine s procjenama obveznika u istraživanjima od 2007. do 2009. godine upućuje na očit porast pozitivnih stavova prema dragovoljnoj vojnoj službi i veću spremnost na uključivanje $u$ nju, kao i porast broja neodlučnih. Negativni stavovi u znatnom su padu. Valja pretpostaviti kako se prikazani pozitivni trend u promjeni stavova prema dragovoljnoj ročnoj službi može obrazložiti povećanom ekonomskom nesigurnošću uvjetovanom recesijskom godinom. Svojevrsna potvrda takve teze jesu i prilično velike regionalne razlike u stavovima o dragovoljnoj ročnoj službi (dijagram br. 11).10

Rezultati ispitivanja po regijama pokazuju najpozitivnije stavove anketiranih prema dragovoljnoj ročnoj službi u Slavoniji (gotovo $47 \%$ anketiranih pristupilo bi dragovoljnom služenju vojnog roka), a slijedi je regija Sjeverozapadna Hrvatska. S druge strane, među anketiranima s područja Grada 
DIJAGRAM 11

Pokazateli razlika u stavovima o dragovoljnom služenju voinog roka po regijama $\rightarrow$ DIJAGRAM 12

Pokazateli zainteresiranosti za mogućnost zapošljavanja u vojsci
Zagreb i prostora Primorja s Likom izrazitiji su negativni stavovi prema dragovoljnoj ročnoj službi. Udio neodlučnih, koji bi možda prihvatili dragovoljnu ročnu službu, najveći je u Dalmaciji (50\%), a još je uvijek izrazito visok i u Slavoniji (oko 35\%).

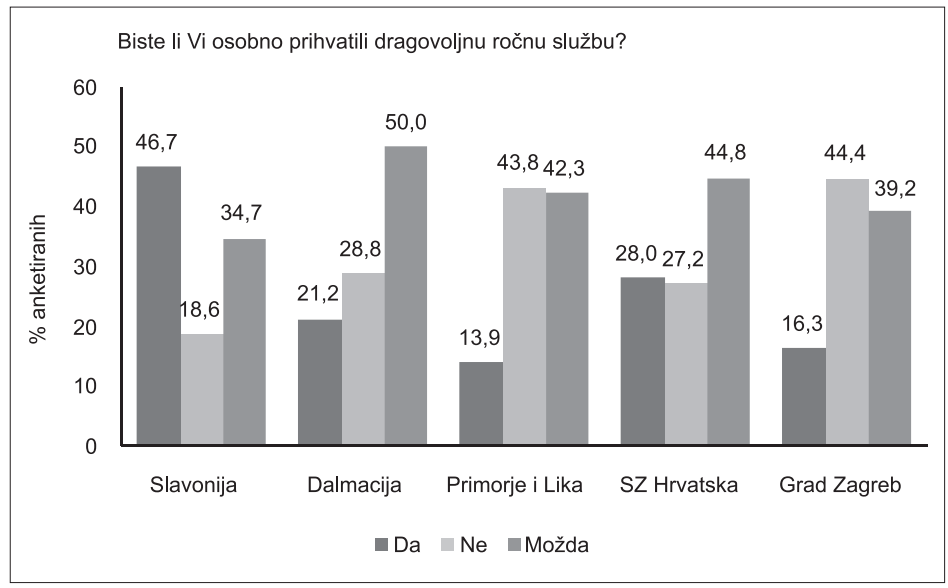

Izvor: Izvješće o stavovima novaka o vojnoj službi tijekom upisa u vojnu evidenciju, 2010., 11

Sličan pozitivan trend (iako znatno manje izražen nego $u$ izjašnjavanju o dragovoljnoj ročnoj službi) vidi se i u rezultatima stavova o ulasku u djelatnu vojnu službu (dijagram br. 12).

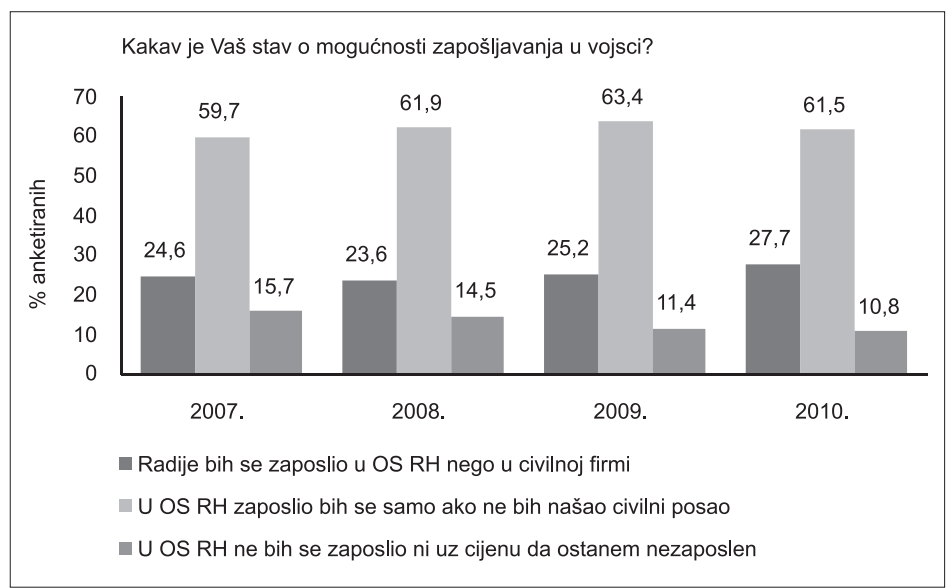

Izvor: Izvješće o stavovima novaka o vojnoj službi tijekom upisa u vojnu evidenciju, 2010., 12

Rezultati pokazuju kako bi se većina ispitanika zaposlila u oružanim snagama samo kad ne bi našli odgovarajući posao u građanstvu (gotovo 62\%), što je nepromijenjeni trend i iz prošlih godina. Isto tako, može se uočiti kako nema značajnijih promjena $\mathrm{u}$ rezultatima ispitivanja iz proteklih godina 
DRUŠ. ISTRAŽ. ZAGREB GOD. 21 (2012)

BR. 1 (115),

STR. $121-136$

MATIKA, D., OGOREC, M. GOSPODARSKA KRIZA..

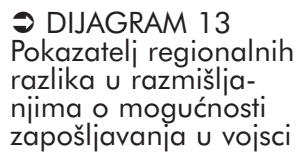

vezanih uz jasne stavove o namjeri zapošljavanja u Oružanim snagama Republike Hrvatske, međutim blagi porast poželjnosti zapošljavanja u Oružanim snagama, u sinergiji s blagim padom nepoželjnosti toga zapošljavanja, ipak je neki pokazatelj koji bi se mogao pripisati utjecaju recesijske godine.

Znatno slabija prepoznatljivost mogućeg utjecaja recesijske godine na stavove ispitanika o djelatnoj vojnoj službi jest u slici regionalnih rezultata, po kojima je poželjnost djelatne vojne službe izražena samo u Slavoniji, dok u ostalim regijama ispitanici o njoj imaju uglavnom izrazito pragmatične stavove (dijagram br. 13).

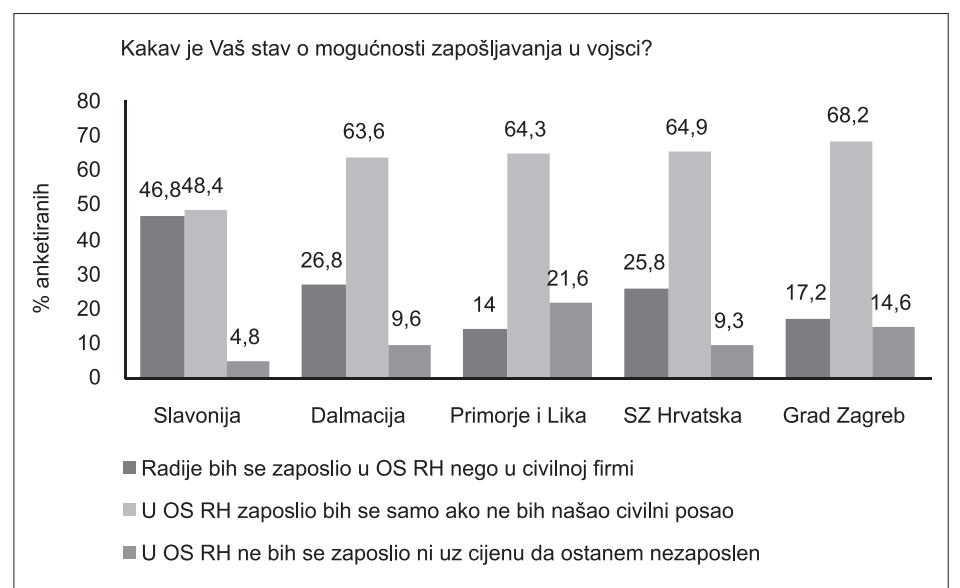

Izvor: Izvješće o stavovima novaka o vojnoj službi tijekom upisa u vojnu evidenciju, 2010., 13

Iz dijagrama se vidi kako su razmišljanja o djelatnoj vojnoj službi kao prihvatljivom obliku zaposlenja najizraženija kod obveznika iz Slavonije (47\%), među kojima je o njoj ujedno u najmanjem postotku (do 5\%) izražen negativan stav, dok u ostalim područjima Hrvatske u vrlo visokom postotku (64-68\%) prevladava razmišljanje o mogućem zapošljavanju u vojsci tek kao o sekundarnom rješenju - samo ako se ne nađe zaposlenje $u$ građanstvu. Iz toga se može zaključiti da će, bez obzira na daljnji razvoj recesije, planovi zapošljavanja i popune Oružanih snaga Republike Hrvatske biti ostvarivi u onoj mjeri u kojoj vojska bude doživljena kao privlačan poslodavac. Pritom se kao najučinkovitija poticajna mjera koja bi učinila djelatnu vojnu službu atraktivnijom i dalje percipira primjerena zarada (dijagram br. 14).

Naime, iz rezultata istraživanja više od $56 \%$ anketiranih potvrdilo je primjerena novčana primanja kao čimbenik koji bi vojnu profesiju učinio privlačnijom, ali isto se tako u velikoj mjeri vrlo stimulativnim čimbenikom shvaća mogućnost profesionalnog razvoja, stručnog usavršavanja i napredovanja $u$ 
DRUŠ. ISTRAŽ. ZAGREB GOD. 21 (2012), BR. 1 (115)

STR. $121-136$

MATIKA, D., OGOREC, M. GOSPODARSKA KRIZA...

DIJAGRAM 14 Pokazatelj učinkovitosti poticajnih miera za zapošljavanje u OS $\mathrm{RH}$ službi. Velik dio ispitanika cijeni i omogućavanje besplatnoga (ili barem subvencioniranoga) školovanja na odgovarajućim školskim ustanovama u Republici Hrvatskoj (oko 41\%), dok bi visoko vrednovano bilo i davanje prednosti pri zapošljavanju u državnim i javnim službama. Ostale ponuđene stimulativne mjere uglavnom su naišle na manji odaziv ispitanika.

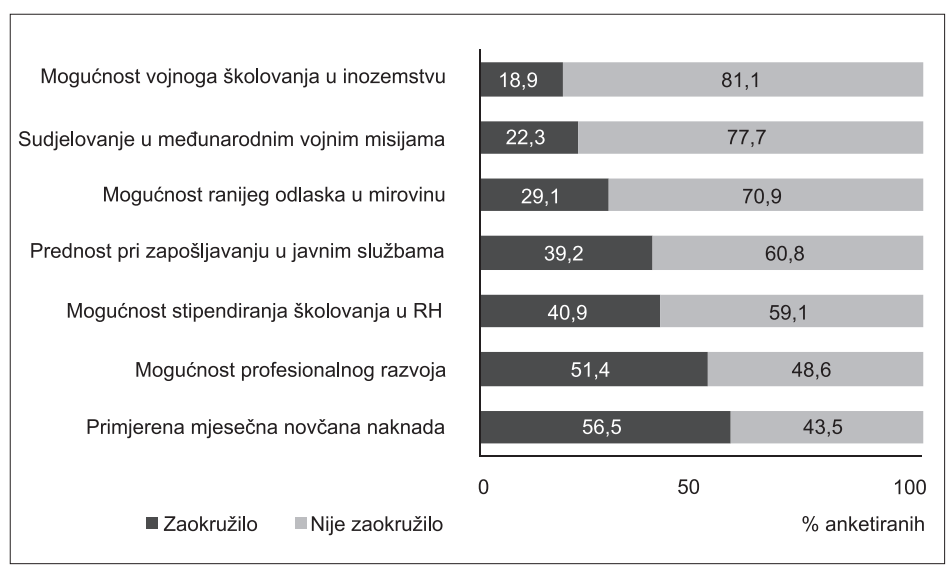

Izvor: Izvješće o stavovima novaka o vojnoj službi tijekom upisa u vojnu evidenciju, 2010., 18

Ekonomsko-financijska kriza, koja se 2009. godine "prelila" iz globalne recesije i na hrvatsko gospodarstvo te dodatno opteretila problematične trendove i dubioze već postojeće, duže vremena endogeno generirane gospodarske krize, multiplicirala je ekonomsku nesigurnost i društva u cjelini i svakoga građanina Republike Hrvatske pojedinačno. Povećana ekonomska nesigurnost utjecala je i na određenu promjenu razmišljanja o poželjnosti i prihvatljivosti službe u Oružanim snagama Republike Hrvatske, pri čemu su Oružane snage u poratnom razdoblju (iako društveno pozitivno ocjenjivane) percipirane kao manje poželjan poslodavac.

Kao jedan od temeljnih zaključaka istraživanja iskristalizirala se činjenica kako među mlađim naraštajima i dalje prevladava pozitivan stav prema Oružanim snagama Republike Hrvatske, što potpuno slijedi opću pozitivnu percepciju vojske $\mathrm{u}$ hrvatskom društvu, izgrađenu na rezultatima Domovinskog rata. U tom kontekstu pozitivnim se ocjenjuje i vojna profesija kao časno i društveno prihvatljivo zanimanje. U skladu s tim, 2009. je godine u nešto većoj mjeri porasla prihvatljivost dragovoljne ročne službe kod anketiranih obveznika upisa u vojnu evidenciju u usporedbi s prethodnim godinama, međutim stavovi prema djelatnoj vojnoj službi nisu se $u$ većoj mjeri promijenili. 
DRUŠ. ISTRAŽ. ZAGREB GOD. 21 (2012), BR. 1 (115)

STR. $121-136$

MATIKA, D., OGOREC, M. GOSPODARSKA KRIZA...

\section{BILJEŠKE}

U sklonosti pristupanju dragovoljnom služenju vojnog roka, a i prihvaćanja djelatne vojne službe kao životnoga (ili barem dugoročnoga) profesionalnog izbora, utvrđene su znatne regionalne razlike. Jedno od mogućih objašnjenja za ove dokumentirane regionalne razlike jest i različita pogođenost regija posljedicama recesije.

Među poticajnim mjerama koje bi vojnu službu učinile atraktivnijom, a oružane snage poželjnijim poslodavcem, anketirani obveznici i dalje na prvo mjesto stavljaju primjerena novčana primanja, ali isto tako visoko vrednuju i određene nematerijalne poticaje, od kojih je najviše rangirano profesionalno usavršavanje i mogućnost napredovanja u službi te otvaranje mogućnosti i perspektive daljnjega školovanja.

Takvi rezultati mogu se tumačiti kao razmišljanje o mogućem privremenom rješenju ekonomske nesigurnosti u razdoblju gospodarske krize, a dugoročno velika većina anketiranih vojnu profesiju doživljava tek kao "izlaz u nuždi", ako se neće moći zaposliti u civilnom sektoru.

${ }^{1}$ Istodobnost pojavljivanja krize na raznim područjima nacionalnih ekonomija gotovo je uvijek ubrzana naraslom međusobnom isprepletenošću pojedinih dijelova gospodarstva, kao i ekonomija raznih država, te povezanošću financijskih tokova, odnosno naraslom pokretljivošću kapitala, ali i nepostojanjem odgovarajućih elemenata reguliranja tržišta koji se danas podrazumijevaju (Ogorec, 2010., 76-77).

2 Npr. građanski rat u Albaniji 1997. nastao je kao posljedica potpunoga financijskog bankrota te najsiromašnije i najzaostalije europske države, uzrokovanoga "financijskim inžinjeringom" koji je doveo do potpunog sloma bankarskoga sustava. Na vrlo sličan način, iscrpljeno diktaturom Nicolaea Ceausescua, te dovedeno na rub potpunoga egzistencijalnog sloma i krajnje bijede, pučanstvo Rumunjske sve je glasnije zahtijevalo radikalne društvene promjene, koje vladajuća oligarhija nije mogla provesti ako je htjela ostati na vlasti. Taj antagonizam doveo je do kratke, ali vrlo žestoke, socijalne revolucije 1989. godine.

3 U cijelom članku autor vrlo kritički preispituje ekonomsku sigurnost u današnjoj globalizirajućoj svjetskoj ekonomiji. U prvom redu postavlja se pitanje mogu li u doba globalizacije pitanja ekonomske sigurnosti biti identificirana isključivo kao nacionalna, pri čemu se upozorava na tezu kako globalizacija samo donosi veću ekonomsku nesigurnost nacionalnih država ili zatvorenijih regija.

4 Politika izjednačavanja nacije s državom te identifikacija privatnih interesa s nacionalnim u jednom dijelu najvišega državnog establišmenta potkraj 1990-ih godina rezultirala je procjenom o stalnoj nacionalnoj ugroženosti, čime je onemogućeno usredotočavanje na stvarne ili vjerojatne izvore ugrožavanja (domaći i međunarodni organizirani kriminal, regionalne krize, ekonomski problemi i sl.). Posljedice takve percepcije bile su, između ostalog, nedjelotvornost $\mathrm{dr}$ žavnih organa, svojevrsno nepoštivanje međunarodno preuzetih obveza Republike Hrvatske i sl., što je neizbježno izazvalo brojne 
DRUŠ. ISTRAŽ. ZAGREB GOD. 21 (2012), BR. 1 (115)

STR. $121-136$

MATIKA, D., OGOREC, M. GOSPODARSKA KRIZA... ekonomske probleme. Pogrešan pristup privatizaciji, visoka državna potrošnja, velika nelikvidnost ekonomije, velika zaduživanja u inozemstvu, nemogućnost privlačenja stranoga kapitala zbog nesigurnosti ulaganja, nepostojanje bilo kakve koncepcije ekonomskog razvoja, tehnološko zaostajanje te visoka stopa nezaposlenosti opterećivali su gospodarstvo zemlje i znatno prije izbijanja međunarodne krize.

5 Odnosi se na razdoblje $\mathrm{u}$ kojem su se provodila ispitivanja, odnosno na veljaču - ožujak 2008. godine. Ispitivanja su rađena za projekt "Hrvatska vojska - hrvatsko društvo". Istraživanje je provedeno terenskom usmenom anketom na uzorku od 3240 ispitanika iz 135 naselja, odnosno 221 lokaciji u Republici Hrvatskoj. Uzorak je probabilistički izabran u naseljima odabranih metodom slučajnog izbora i stratificiranih u četiri razine određene stupnjem urbaniziranosti (Smerić i sur., 2008., 7).

6 Ispitanici su ocjenjivali pojedine elemente ključne za učinkovitost oružanih snaga ocjenama od 1 do 5 , pri čemu je ocjena 1 davala najnižu vrijednost, a ocjena 5 najvišu (Franc i sur., 2008., 42).

7 Ispitanici su ocjenjivali ugled vojne profesije na ljestvici od 1 ("Izrazito visok društveni ugled") do 8 ("Izrazito nizak društveni ugled"), pri čemu su ocjene 1,2 i 3 vrednovane pozitivnima i umjereno pozitivnim, 4 i 5 umjerenim prosjekom, a 6, 7 i 8 donekle negativnim i negativnim. Rezultati su izraženi u postocima ispitanika koji su se odlučili za pojedinu ocjenu.

8 Battistelli, F. (1997.), Peacekeeping and the Postmodern Soldier. Armed Forces and Society, 23 (3): 467-484.

${ }^{9} \mathrm{U}$ skladu s tim, u 2007. godini ispitana su 1882 obveznika upisa u vojnu evidenciju, u 2008. i 2009. godini anketirana su po 1440 obveznika, a u 2010. godini 1445 obveznika (Izvješće o stavovima novaka o vojnoj službi tijekom upisa u vojnu evidenciju 2010., 5).

10 Temeljitiju i kvalitetniju potvrdu navedene teze dalo bi veće razgraničenje $\mathrm{u}$ ispitivanju, koje nažalost nije provedeno zbog pojednostavnjenja cjelokupnoga postupka. Tako bi vjerojatno drugačiji podaci bili kada bi se posebno prikazali rezultati Primorja, posebno Istre i posebno Like, koji su u ovom ispitivanju objedinjeni.

\section{LITERATURA}

Dent, C. (2010.), Ekonomska sigurnost. U: A. Collins (ur.), Suvremene sigurnosne studije (str. 233-253), Politička kultura, Zagreb.

Franc, R., Ivičić, I. i Rihtar, S. (2008.), Hrvatski nacionalni identitet i identitet Hrvatske vojske, Izvješće, Institut društvenih znanosti Ivo Pilar, Zagreb.

Hrvatska u brojkama 2010. (2010.), Državni zavod za statistiku Republi-

Izvješće o stavovima novaka o vojnoj službi tijekom upisa u vojnu evidenciju (rujan 2010.), Odsjek za vojnu psihologiju Personalne službe, Ministarstvo obrane Republike Hrvatske, Zagreb.

Kahler, M. (2004.), Economic Security in an Era of Globalisation: Definition and Provision. The Pacific Review, 17 (24): 485-502, http://irps. ucsd.edu/assets/014/6745.pdf (13. 1. 2011.). doi:10.1080/0951274042000 326032 ke Hrvatske, Zagreb. 
DRUŠ. ISTRAŽ. ZAGREB GOD. 21 (2012)

BR. 1 (115),

STR. $121-136$

MATIKA, D., OGOREC, M. GOSPODARSKA KRIZA...
Ogorec, M. (2010.), Izazovi kriznog upravljanja, Veleučilište u Velikoj Gorici, Velika Gorica.

Petrov, T. (2008.), Koliko je duboka domaća gospodarska kriza?, http://www. poslovni.hr/vijesti/ (13. 01. 2011.)

Smerić, T. (2001.), Društveni ugled časničke profesije u Hrvatskoj - pogled iznutra. Polemos, 4 (2): 11-31.

Smerić, T. (2005.), Sparta usred Babilona?, Hrvatska sveučilišna naklada, Zagreb.

Smerić, T., Mišetić, A. i Rihtar, S. (2008.), Stavovi hrvatske javnosti spram Hrvatske vojske, Izvješće, Institut društvenih znanosti Ivo Pilar, Zagreb.

Smerić, T., Franc, R. i Sučić, I. (2009.), Stavovi kadeta OS RH - Hrvatski nacionalni identitet i identitet Hrvatske vojske, Izvješće, Institut društvenih znanosti Ivo Pilar, Zagreb.

\section{The Economic Crisis and the Desirability of Choosing the Military Call}

Dario MATIKA, Marinko OGOREC

Institute for Research and Development of

Armed Systems of MORH, Zagreb

In the circumstances of elevated personal uncertainty, due to the economic-financial crisis which strongly affected the Republic of Croatia as well, the desirability of choosing the military profession has changed as well to a certain extent. Since the economic crisis appeared in the Republic of Croatia and along with it personal economic insecurity, the approach of younger generations towards the military profession has begun to alter as well as the attitude towards their own enrolment in the military forces as a life (or at least long-term) choice. The research has shown that in year 2010 the acceptance of voluntary maturity service with the questioned conscripts has somewhat increased with regard to previous years. However, the attitudes towards active military service have not changed considerably. Such results could be interpreted as thoughts about possible temporary solutions for economic insecurity in the period of recession, while in the long run, the majority of questioned soldiers consider the military profession merely as an "emergency exit" in case they aren't able to find employment in the public sector.

Keywords: economic crisis, military profession, voluntary military service 